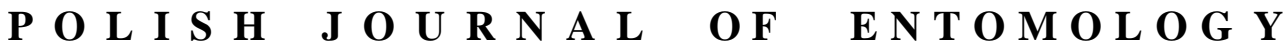

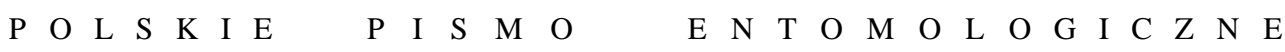

VOL. 83: 99-107

Lublin

30 June 2014

DOI: $10.2478 /$ pjen-2014-0007

\section{Contribution to knowledge of the distribution of the rare great silver water beetle Hydrophilus piceus (LINNAEUS, 1758) (Coleoptera, Hydrophilidae) in Greece}

\section{IOANNIS KARAOUZAS, ARGYRO ANDRIOPOULOU, KONSTANTINOS GRITZALIS}

Hellenic Centre for Marine Research, Institute of Marine Biological Resources and Inland Waters, 46.7km Athens-Sounio Av., 19013 Anavissos, Attica, Greece, e-mail: ikarz@hcmr.gr

\begin{abstract}
This study contributes to the currently poor knowledge of the distribution of Hydrophilus piceus (LINNAEUS, 1758) in Greece, an important and elsewhere threatened and critically endangered aquatic beetle. The large great silver water beetle was recorded in various aquatic habitats in the north-western Peloponnesus, being the southernmost record of the species in Greece. Photographs of the adult of the species are presented, and some notes on its ecology are provided. This work highlights the importance of revising the current status of the species in Greece, protecting its habitat and including it as a target species for conservation efforts.
\end{abstract}

KEY WORDS: Coleoptera, Hydrophilidae, Hydrophilus piceus, distribution, aquatic beetle, Greece.

\section{INTRODUCTION}

The great silver water beetle Hydrophilus piceus (LINNAEUS, 1758) is one of the largest aquatic insects with a wide Palaearctic range extending from southern Scandinavia to the Mediterranean, in northern Africa (known only in Egypt), most of north-eastern Europe and Siberia to northern India (Kashmir) (HANSEN 1999, 2004). Adults often exceed $40 \mathrm{~mm}$ in length, are omnivorous but feed primarily on plant material. H. piceus is considered an annual species with non-overlapping generations that most probably die during the summer after breeding (BEEBEE 2007); however, it has been known to live for 2-3 years (HANSEN 
1987). Larvae feed principally on freshwater snails (Planorbidae, Lymnaeidae), making characteristic holes in the shells of their victims, and can grow rapidly up to $70 \mathrm{~mm}$ in length before pupating on land during summer, usually in soft mud near the water's edge. Shortly after mating, females produce a floating cocoon filled with eggs in late April or early May. Adults of the next generation emerge by or before autumn (BALFOUR-BROwNE 1958).

Hydrophilus piceus is considered to be extinct (EX) in Luxemburg (GEREND 2003) and Norway (ØDEGAARD et al. 2006), critically endangered (CR) in the Czech Republic (TRÁVNí́̌́EK et al. 2005), vulnerable (VU) in Slovakia (HoleCOVÁ \& FRANC 2001), and near threatened (NT) in Poland (PAWŁOWSKI et al. 2002), Sweden (GÄRDENFORS 2005) and the UK (FOSTER 2010). In Greece, very little is known about its current population status or its distribution in aquatic environments. Based on the available literature, $\mathrm{H}$. piceus has only been reported from the Axios Delta as a food source of herons (KAZANTZIDIS \& GOUTNER 2005). As with many other insect groups, the coleopteran fauna of Greece is relatively unknown.

The aim of this contribution is to enhance knowledge of the distribution of Hydrophilus piceus in Greece and to highlight the importance of revising the current status of the species and including it as a target species for conservation efforts.

\section{MATERIALS AND METHODS}

Adult specimens were recorded from the estuary of the River Pineios and the Prokopos Lagoon in the Western Peloponnesus (Fig. 1). Specimens were collected using a rectangular $25 \times 25 \mathrm{~cm}$ hand net with a $500 \mu \mathrm{m}$ mesh nytex screen, but whenever possible were simply picked by hand and identified on site. Adult specimens were identified with the taxonomic key of INCEKARA et al. (2003). A single specimen, described in this contribution, is preserved and deposited in the collection of the Institute of Marine Biological Resources and Inland Waters, Hellenic Centre for Marine Research, Anavissos, Greece.

\section{RESULTS}

\section{Systematics and general distribution}

Genus: Hydrophilus GEOFFROY 1762

Species: Hydrophilus piceus (LINNAEUS, 1758)

Synonymous:

Dytiscus piceus LINNAEUS, 1758 
Hydrophilus angustior REY, 1885

Hydrophilus niger EICHLER, 1876

Hydrophilus ruficornis DE GEER, 1774

Hydrophilus viridicollis REDTENBACHER, 1844

Hydrous turkestanus KUWERT, 1893

Stethoxus plicifer BEDEL, 1891

Meaning of the species name: piceus: pitch black (descr., Latin), adj. inflect.

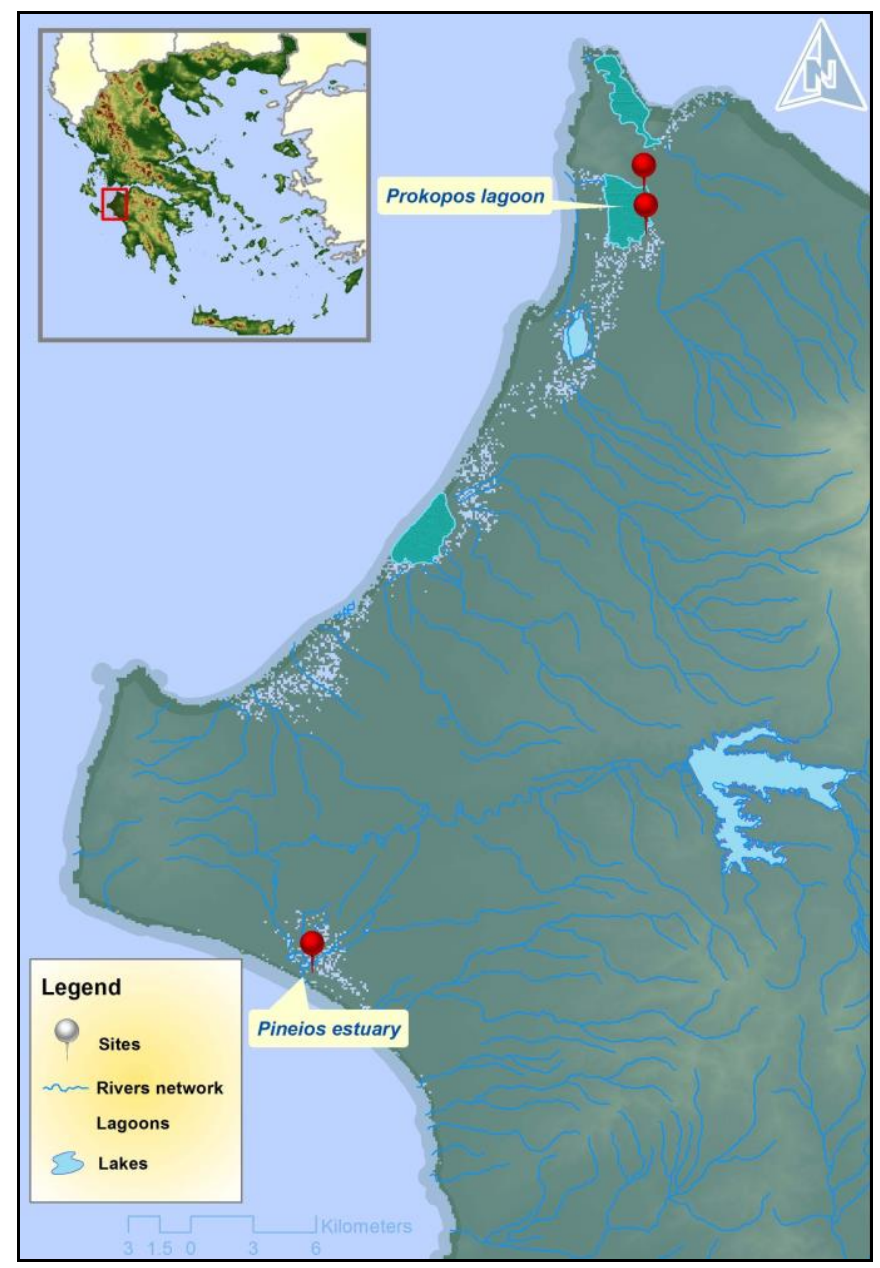

Fig. 1. Localities where Hydrophilus piceus was recorded. 
Distribution: Palaearctic: Algeria, Austria, Belgium, Bosnia-Herzegovina, Britain, Bulgaria, Caucasus, China, Croatia, Czech Republic, Denmark, Egypt, Finland, France, Germany, Greece, Hungary, Iran, India, Israel, Italy, Lebanon, Lithuania, Former Yugoslav Republic of Macedonia, Montenegro, Netherlands, Norway, Poland, Romania, Russia, Serbia, Slovakia, Slovenia, Spain, Sweden, Switzerland, Syria, Turkey, Ukraine and Uzbekistan (HEBAUER 1994, HANSEN 1999, InCEKARA et al. 2003, 2009, HeNDRICH \& HENDRICH 2005, KIYAK et al. 2006, GHAHARI \& JĘDRYCZKOWSKI 2011).

\section{Material examined}

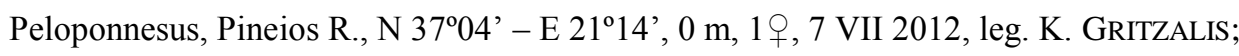

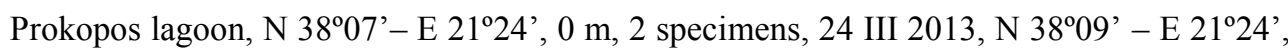
$0 \mathrm{~m}, 1$ specimen, leg. I. KARAOUZAS.

\section{Description of the adult}

Body oval and black with metallic olive (dark green) reflections, $51.5 \mathrm{~mm}$ in length and $20.5 \mathrm{~mm}$ in width. Elytra $33.5 \mathrm{~mm}$ long and $20.5 \mathrm{~mm}$ wide. Head $10 \mathrm{~mm}$ long and wide. Length and width of pronotum $8 \mathrm{~mm}$ and $16 \mathrm{~mm}$, respectively. Clypeus with welldeveloped systematic punctures. Eyes dark and protruding. Maxillary palpi elongated, with asymmetrical apical segments. Antennae 9-segmented, reddish black. Pronotum widest at base, clearly narrowed anteriorly, sinuate at anterior and posterior margins. Ventral surface black, mesosternal keel long (Fig. 2).

\section{DISCUSSION}

\section{Morphological characters}

No distinct morphological characteristics were found based on species descriptions from other areas (e.g. INCEKARA et al. 2003) or among the first descriptions of the species (REGIMBART 1901, MiALl 1922).

\section{Ecology and distribution}

The distribution and habitat preferences of Hydrophilus piceus in Greece are largely unknown. Up to now, the recorded distribution of the species in Greece is confined to estuaries and lagoons from three locations (Fig. 3); however, it is anticipated that it extends to many more areas. In other countries, apart from the lowlands, H. piceus has been found in lakes and ponds at higher altitudes, even reaching 1000 m (KIYAK et al. 2006, DARILMAZ et al. 2010). 


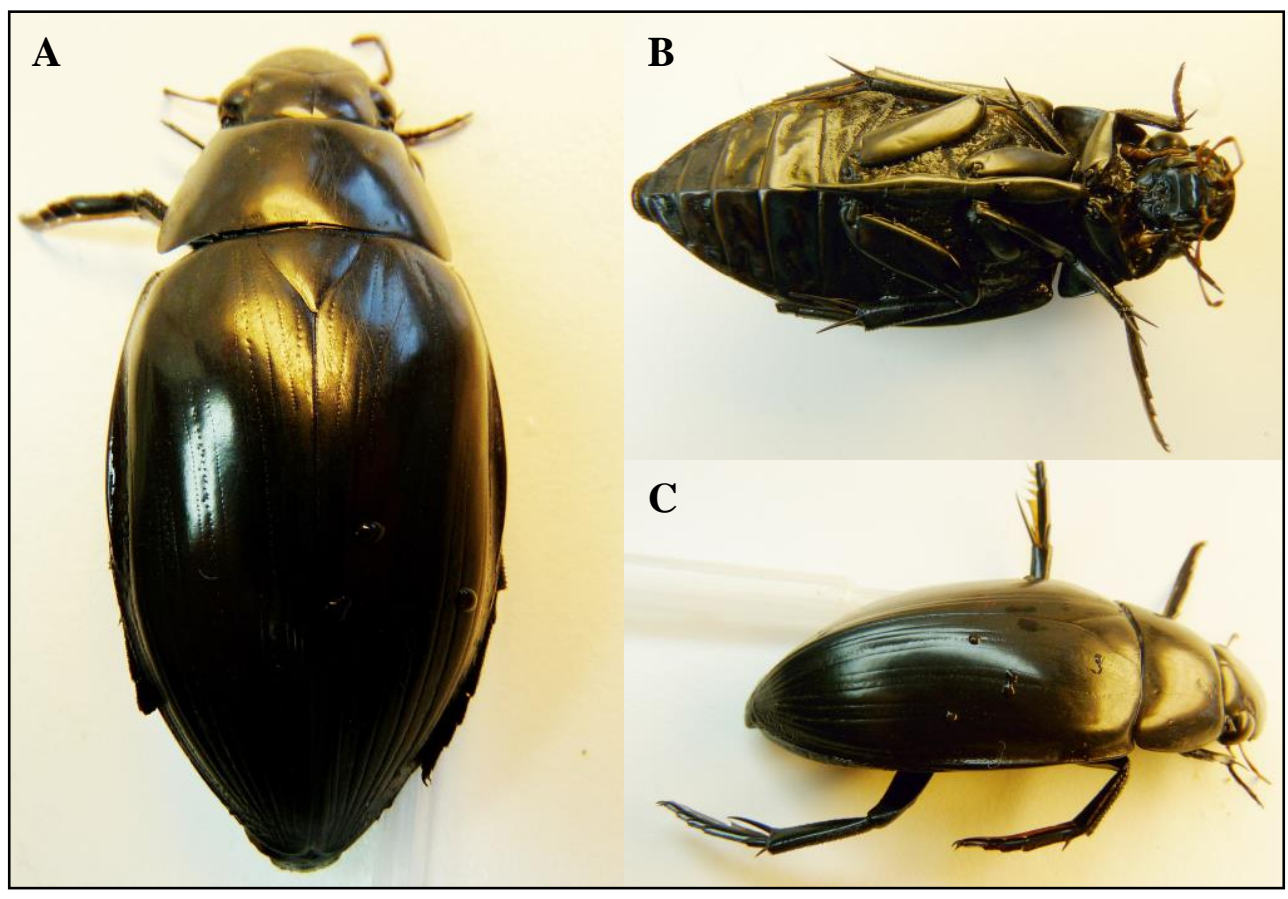

Fig. 2. Adult female Hydrophilus piceus: dorsal view (A), ventral view (B), lateral view (C).

The preserved individual was collected from the banks of the River Pineios close to its mouth, approximately $180 \mathrm{~m}$ before the sea and at depths of $40-45 \mathrm{~cm}$. The vast majority of the river bank is covered with reeds (Arundo donax LINNAEUS, 1753) as well as small clumps of Tamarix sp. The waters were almost lentic (non-visible flow), deep (app. $2.5 \mathrm{~m}$ ), eutrophic with muddy bottom substratum, well oxygenated (D.O $7.69 \mathrm{mg} \cdot \mathrm{dm}^{-3}$ ) and warm $\left(26.2^{\circ} \mathrm{C}\right)$; salinity was $1 \mathrm{ppt}$, and the conductivity $\left(1992 \mu \mathrm{S} \cdot \mathrm{cm}^{-2}\right)$ and total dissolved solids $\left(1403 \mathrm{mg} \cdot \mathrm{dm}^{-3}\right)$ were relatively high.

The remainder of the recorded specimens were found in the Prokopos Lagoon, a RAMSAR shallow water body listed under the NATURA 2000 network (GR 2320001 Kalogria Lagoon, Strofylia Forest and Lamia Marsh). The waters there are lentic, shallow $(30-80 \mathrm{~cm})$ and warm $\left(20^{\circ} \mathrm{C}\right)$, eutrophic with a muddy substratum, well oxygenated $(12.3$ $\mathrm{mg} \cdot \mathrm{dm}^{-3}$ ) and with a salinity of $1.5 \mathrm{ppt}$ (at the time of sampling). The lagoon has a rich vegetation including Lemna gibba (LINNAEUS, 1753), Ruppia cirrhosa (PETAGNA) Grande, 1918, Potamogeton pectinatus (LINNAEUS, 1753), Chaetomorpha ligustica (KÜTZING, 1849), Ulva intestinalis (LINNAEUS, 1753), Chara hispida ssp. corfuensis (J. Groves ex N. FILRSZKY) R.D. WoOD, 1962 and Chara canescens J.L.A. LOISELEURDESLONGSCHAMPS, 1810 (FYTTIS 2011). 


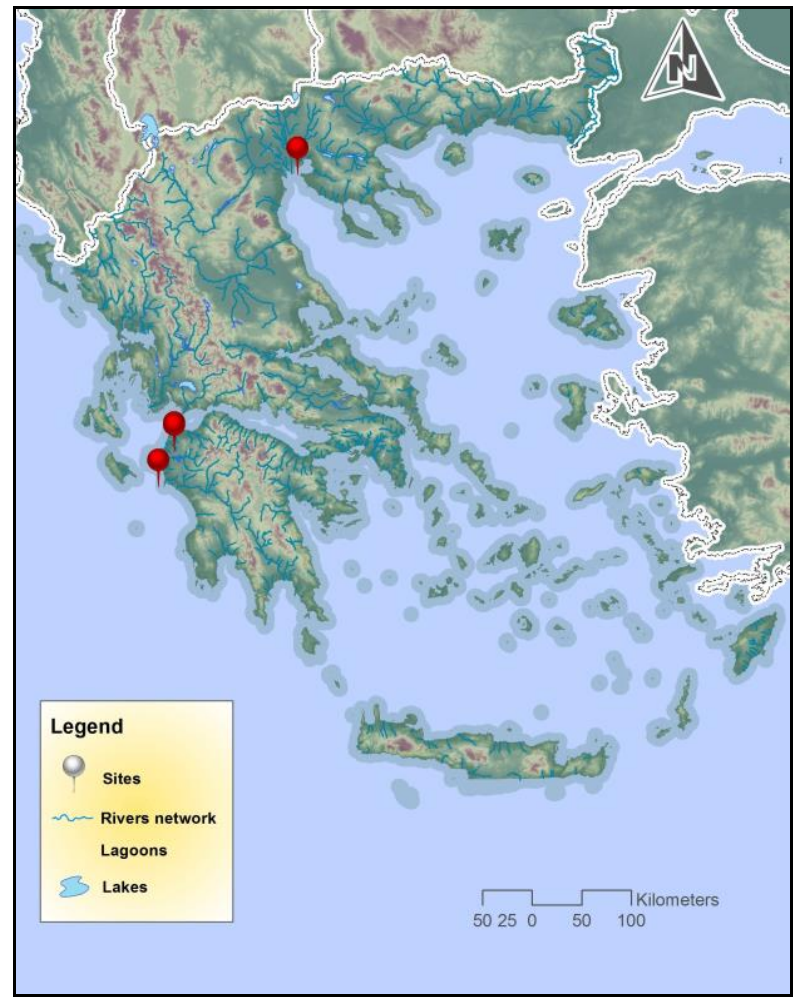

Fig. 3. Known distribution of Hydrophilus piceus in Greece.

It must be pointed out that these are the first records of $H$. piceus in these two aquatic systems. Noteworthy is the occurrence of H. piceus in the Prokopos Lagoon, where it must be considered very rare, since it was not found during a two-year seasonal monitoring study conducted in 2009-2010 (FYTTIS 2011).

In Britain, $H$. piceus is rare and within historical times has been found only in low-lying marshy habitats in the south and east of England (FOSTER, 1987). It is largely confined to drains in coastal levels with rich vegetation such as Lemna trisulca (LINNAEUS, 1753) and the common reed Phragmites australis (CAVANILLES) TRINIUS ex STEUdEL, 1841. In a relatively recent study carried out by BOYCE (2004), H. piceus was found to show a preference for permanent open ditches with abundant emergent and/or submerged macrophytes but never for shallow, shaded ditches favoured by breeding Hydrochara caraboides (LINNAEUS, 1758). Currently in Britain, there are six extensive areas of habitat that support substantial populations of the beetle: the Somerset Levels, the Lewes Brooks, the Pevensey Levels, the Romney-Walland marshes, the North Kent marshes and the 
Waveney valley marshes in Norfolk (BEEBEE 2007). In addition, there are four smaller sites that support breeding populations, conspicuously in the Gwent levels, south-east Essex, and two sites in Suffolk (BEEBEE 2007). FOSTER (2010) gives a detailed and rigorous report on the current status of the species in Britain.

In the Iberian Peninsula, $H$. piceus is confined to a few well-vegetated lagoons in the Pyrenean region in the Ebro delta and coexists with Hydrophilus pistaceus LAPORTE DE CASTElnaU, 1840, a western Mediterranean species common in the Iberian Peninsula (RIBERA et al. 1996). In Italy, it has been recorded in rice fields and irrigation channels in the basin of the River Po (LUPI et al. 2013). In Turkey, the distribution of H. piceus seems to be broad and has so far been recorded from Çorum, Denizli, Erzurum, Kayseri and Samsun (INCEKARA et al. 2003, 2009, KIYAK et al. 2006, DARILMAZ et al. 2010). Several other records from various countries exist (e.g. Iran, Uzbekistan, Hungary, Italy, etc.) but these are part of a wider macroinvertebrate or faunistic study and only the number of specimens collected is reported, which is usually very low (i.e. 1-5 adults).

\section{Threats and conservation measures}

Hydrophilus piceus is globally considered rare (RDB 3) according to the original IUCN Red list categories. The main threats to $H$. piceus are pollution, habitat destruction such as loss of traditional grazing fen, clear cutting, etc. For example, drainage of the Cambridgeshire Fens and the London Marshes in the $19^{\text {th }}$ Century must have resulted in the greatest reductions in this species in Britain (FOSTER 2010). A study conducted on the population structure of $\mathrm{H}$. piceus in Britain by BEEBEE (2007) suggests that the species could be very vulnerable to environmental change, whether of climate or habitat. Information about the population structure of $\mathrm{H}$. piceus would certainly be useful in future conservation planning. Conditions favouring the breeding of the species, such as an abundance of molluscs, which the species feeds on, are essential. Clearance of drains using hand shovels is preferable to the use of heavy machinery, which virtually wipes out the macroinvertebrate fauna, and clearance of reeds or other vegetation by burning should be avoided.

\section{Conclusions}

The current population and distribution status of Hydrophilus piceus in Greece is unknown. As habitat destruction and pollution from agricultural wastes, including fertilisers and pesticides, is significant in many Greek rivers and wetlands, the population of this beetle may be critical without being acknowledged as such. Monitoring programmes should be implemented to evaluate its distribution and population status so that immediate measures for its protection and conservation can be implemented. 


\section{REFERENCES}

BALfour-Browne F. 1958. British Water Beetles, Vol. III. Ray Society, London.

BEEBEE T. 2007. Population structure and its implications for conservation of the great silver beetle Hydrophilus piceus in Britain. Freshwater Biology 52(11): 2101-2111.

BouZID S., InCEKARA Ü. 2006. Distributional Notes on Northeastern Algerian Hydrophilidae (Coleoptera), with Three New Records. Turkish Journal of Zoology 30(3): 305-308.

BOYCE D.C. 2004. A study of the distribution and ecology of the lesser silver water beetle Hydrochara caraboides on the Somerset Levels. English Nature Research Reports 591: 1-69.

Darilmaz M.C., Salur A., Mesci S. 2010. Aquatic Coleoptera fauna of Çorum and Yozgat Provinces (Turkey). Biological Diversity and Conservation 3(2): 89-96.

Foster G.N. 2010. A review of the scarce and threatened Coleoptera of Great Britain Part (3): Water beetles of Great Britain. Species Status 1. Joint Nature Conservation Committee, Peterborough.

FYTTIS G. 2011. Ecological quality monitoring of Kotychi \& Prokopos Lagoons of W. Greece: an analysis of aquatic macrophyte and macroinvertebrate assemblages within the framework of the Water Directive 2000/60/EC. MSc Thesis, University of Patras. (in Greek).

GÄRDENFORS U. 2005. Red List of Swedish species 2005. ArtDatbanken, SLU, Uppsala. (in Swedish).

GEREND R. 2003. Vorläufiges Verzeichnis der Wasserkäfer Luxemburgs (Coleoptera: Hydradephaga, Hydrophiloidea part., Dryopoidea part., Microsporidae, Hydraenidae, Scirtidae). Bulletin de la Société des Naturalistes Luxembourgeois 104: 67-78.

GHAHARI H., JĘDRYCZKOWSKI W.B. 2011. A faunistic survey on some families of Coleoptera (Insecta) from Iran. Calodema 175: 1-4.

HAnsen M. 1987. The Hydrophiloidea (Coleoptera) of Fennoscandia and Denmark. Fauna Entomolgica Scandinavica, Volume 18. EJ Brill/Scandinavian Science Press Ltd., Leiden Copenhagen.

HANSEN M. 1999. World Catalogue of Insects, Vol. 2: Hydrophiloidea (s. str.) (Coleoptera). Apollo Books, Copenhagen.

Hansen M. 2004. Family Hydrophilidae Latreille, 1802. [in:] Löbl I., Smetana A. (eds.) Catalogue of Palaearctic Coleoptera, 2. Hydrophiloidea - Histeroidea - Staphylinoidea. Apollo Books, Copenhagen, 44-68.

Hebauer F. 1994. The Hydrophiloidea of Israel and the Sinai (Coleoptera, Hydrophiloidea). Zoology in the Middle East 10(1): 73-137.

Hendrich L., Hendrich E. 2005. A contribution to the knowledge of the water beetle fauna of Uzbekistan (Coleoptera: Hydradephaga, Hydrophiloidea, Staphylinoidea and Dryopoidea). Linzer Biologische Beiträge 37(1): 425-434.

HolecovÁ M., Franc V. 2001. Červený (ekosozologický) zoznam chrobákov (Coleoptera) Slovenska. [in:] BALAŽ D., MARHOLD K., URBAN P. (eds). Červený zoznam rastlìn a živočíchov Slovenska. Ochrana prírody 20(Suppl.): 111-128. (In Slovak) 
İncekara Ü., Darilmaz M.C., Mart A., Polat A., Karaca H. 2009. Faunistic study on two sister plain (Bafra and Çarşamba) aquatic Coleoptera fauna in Turkey: Two similar geography but rather different fauna, with a new record. Munis Entomology \& Zoology 4(1): 125-138.

InCEKARA Ü., Mart A., ERMan O. 2003. Check List of the Hydrophilidae (Coleoptera) species of Turkey and a new record for the Turkish fauna. Turkish Journal of Zoology 27(1): 47-53.

KaZANTZiDis S., Goutner V. 2005. The diet of nestlings of three Ardeidae species (Aves, Ciconiiformes) in the Axios Delta, Greece. Belgian Journal of Zoology 135(2): 165-170.

Kiyak S., Canbulat S., Salur A., Darilmaz M. 2006. Additional notes on aquatic Coleoptera fauna of Turkey with a new record (Helophoridae, Hydrophilidae). Munis Entomology \& Zoology 1(2): 273-278.

Lupi D., Rocco A., Rossaro B. 2013. Benthic macroinvertebrates in Italian rice fields. Journal of Limnology 72(1): 184-200.

Miall L.C. 1922. The great water-beetle Hydrophilus piceus. [in:] Miall L.C. (ed.). The natural history of aquatic insects. Macmillan \& Co., London, 61-87.

O’NeIL P., BeEBEe T.J.C. 2005. The great silver water beetle in Britain - a cry for help. British Wildlife 16(4): 265-269.

ØdegaArd F., Andersen J., Hanssen O., Kvamme T., Olberg S. 2006. Biller Coleoptera. In KÅLÅs J.A., VIKEN Å., \& BAKKEN T. (eds). Norwegian Red List. Artsdatabanken, Trondheim, $237-266$.

PawŁowski J., Kubisz D., Mazur M. 2002. Coleoptera. The Beetles. [in:] GŁowaciński Z. (ed.). Red List of Threatened Animals in Poland. Institute of Nature Conservation PAN, Kraków, 88-110. (in Polish)

Ribera I., Bilton D.T., Aguilera P., Foster G.N. 1996. A North African-European transition fauna: water beetles (Coleoptera) from the Ebro delta and other Mediterranean coastal wetlands in the Iberian peninsula. Aquatic Conservation: Marine and Freshwater Ecosystems 6(3): 121-140.

TrávNíček D., FirkáČeK M., Boukal M. 2005. Hydrophiloidea (vodomilové). [in:] FARKaČ J., KRÁl D., ŠKORPíK M. (eds). Red list of threatened species in the Czech Republic. Invertebrates. Agentura ochrany prírody a krajiny ČR, Praha, 422-424. (in Czech)

Received: 15 December 2013

Accepted: 21 February 2014 